\title{
KNOWLEDGE AND AWARENESS OF RISK FACTORS FOR CARDIOVASCULAR DISEASE IN THE GA-RANKUWA COMMUNITY
}

\section{Li Yuqiu}

MTech student

MTech: Nursing, Adelaide Tambo School of Nursing Science, Tshwane University of Technology, Tshwane

\author{
Susanna Catherina Dreyer Wright \\ DTech: Nursing \\ Senior Lecturer, Adelaide Tambo School of Nursing Science, Tshwane University of Technology, Tshwane \\ Corresponding author: wrightscd@tut.ac.za
}

Keywords: knowledge and awareness; cardiovascular disease; risk factors; behaviour change; black population; Ga-Rankuwa

\begin{abstract}
Cardiovascular disease causes $30 \%$ of deaths globally. By comparison, infectious disease accounts for $10 \%$ of global mortality. As these statistics indicate, cardiovascular disease is the most common cause of death in the world. In South Africa, through urbanisation and changes in lifestyle and dietary habits, the prevalence of risk factors and, by extension, the resulting morbidity and mortality from cardiovascular disease in black people, are expected to increase. Owing to the natural progression of the disease, the first 'westernised illness' is hypertension, which is very prevalent among the black population. Knowledge and awareness of risk factors are essential components of behaviour change; however, little is known about the knowledge and awareness of cardiovascular disease among the working-age people in the Ga-Rankuwa community. The purpose of the study was therefore to determine the knowledge and awareness of the identified risk factors among the working-age people (18-40 years old) in the Ga-Rankuwa community. The design was a quantitative survey. The study sample $(n=604)$ was selected from zones 1, 2, 4 and 16 of Ga-Rankuwa to determine the prevalence of risk factors for cardiovascular disease. Only people with an identified risk factor were included in the knowledge and awareness survey $(n=551)$. Data was gathered from July to October 2005. The data gathering was self-reported with a structured questionnaire. Data were analysed using descriptive statistics and statistical analysis. The results obtained from the knowledge and awareness survey indicate that knowledge and awareness of the risk factors for cardiovascular disease are low in the Ga-Rankuwa community.
\end{abstract}

\section{OPSOMMING}

Kardiovaskulêre siektes veroorsaak $30 \%$ van sterftes wêreldwyd. In vergelyking veroorsaak aansteeklike siektes net $10 \%$ van die sterftes wêreldwyd. Kardiovaskulêre siektes is dus die mees algemene oorsaak van sterftes. In Suid-Afrika, as gevolg van verstedeliking en gepaardgaande veranderende dieetgewoontes en lewenstyl, is die verwagting dat die voorkoms van risikofaktore in swartmense sal verhoog en daarmee saam ook die gevolglike morbiditeit en mortaliteit aan kardiovaskulêre siektes. Hipertensie is die eerste 'westerse siekte' vanweë die natuurlike verloop van kardiovaskulêre siektes en is meer algemeen in die swart gemeenskap. Kennis en bewustheid van die risikofaktore is 'n noodsaaklike komponent om die nodige gedragsverandering te bewerkstellig, maar min inligting is oor die vlak van kennis en bewustheid van kardiovaskulêre siektes in die Ga-Rankuwa-gemeenskap beskikbaar. Die doel van die studie was dus om die kennis en bewustheid van risikofaktore vir kardiovaskulêre siektes in 'n werksouderdom groep persone (18-40 jaar oud) in Ga-Rankuwa te bepaal. ' $n$ Kwantitatiewe opname is uitgevoer. ' $n$ Sensussteekproef is vanuit sone 1, 2, 4, and 16 in Ga-Rankuwa getrek om die voorkoms van risikofaktore vir kardiovaskulêre siektes te bepaal ( $n=604)$. ' $n$ Subgroep persone, slegs dié wat met ' $n$ risikofaktor vir kardiovaskulêre siektes diagnoseer is, is in die opname ingesluit ( $n=551)$. Die data is vanaf Julie tot Oktober 2005 deur middel van 
selfrapportering en 'n gestruktureerde vraelys ingesamel en is deur beskrywende statistiek ontleed. Die resultate dui daarop dat daar oor die algemeen 'n lae vlak van kennis en bewustheid van die risikofaktore vir kardiovaskulêre siektes in die Ga-Rankuwa-gemeenskap is.

\section{BACKGROUND, RATIONALE AND RE- SEARCH PROBLEM}

Cardiovascular disease causes $30 \%$ of deaths globally. By comparison, infectious diseases account for $10 \%$ of global mortality (Anderson \& Chu, 2007:209). As these statistics indicate, cardiovascular disease is the most common cause of death in the world. Risk factors for cardiovascular disease include obesity, hypertension, type 2 diabetes mellitus, physical inactivity, increased waist-hip ratio, elevated high-density lipoprotein cholesterol, smoking and increased alcohol consumption (Smeltzer \& Bare, 1996:640). To compound the situation, the risk factors for cardiovascular disease are interlinked with more than one chronic non-communicable disease.

Obesity is a case in point. McTigue, Larson, Valoski, Burke, Kotchen, Lewis, Stefanick, Van Horn and Kuller (2006:79) state that the degree of health risk facing obese women varies with the degree of their obesity. Obese women have a higher prevalence of hypertension, diabetes and hyperlipidaemia. Hossain, Kawar and El Nahas (2007:213) report that obesity has trebled in developing countries over the past 20 years. Obesity is a risk factor not only for cardiovascular disease, but also for type 2 diabetes, degenerative joint diseases, gallbladder diseases, various cancers (for example breast and colon), skin problems and infertility (WHO, 2003). Hossain et al. (2007:213) emphasise that fundamental social and political changes have to take place to tackle cardiovascular disease, obesity and diabetes.

In South Africa, through urbanisation and changes in lifestyle and dietary habits, the prevalence of risk factors and, by extension, the resulting morbidity and mortality from cardiovascular disease in black people, are expected to increase. Walker, Ballard, Raal, Vermaak, Delport, Shor and Brink (2000:36) warn that the first 'westernised illness' is hypertension, which is very prevalent among the black population. The next phase is diabetes mellitus, and the next, 15-20 years later, is atherosclerosis. Bradshaw, Nannan, Laubser,
Groenewald, Joubert, Nojilana, Norman, Pieterse and Schneider (2003:6) report that there is little difference between the provinces in terms of the age-standardised death rate due to non-communicable disease approximately 750 deaths per 100000 of the population. However, the death rates for specific conditions do vary, with stroke and ischaemic heart disease being the most common cardiovascular causes of death. Ischaemic heart disease is the fourth highest cause of premature mortality in Gauteng (Bradshaw et al., 2003: Done:9).

One of the strategies commonly employed for the prevention and management of cardiovascular disease has been education of patients and the public. Although this approach does not guarantee changes in behaviour among individuals, it is generally viewed as an essential ingredient in the process of change (Kirkland, Maclean, Langille, Joffres, MacPherson \& Andreou, 1999:col.161). Modifications of cardiovascular risk factors require a change in lifestyle habits and behaviours. Changes in lifestyle need to take place early in a person's life to utilise the full prevention value of the change. Knowledge and awareness of risk factors are essential to behaviour change. Little is known about the level of knowledge and awareness of cardiovascular disease among the working-age people in the Ga-Rankuwa community.

\section{RESEARCH PROBLEM}

Cardiovascular disease has become one of the main health concerns everywhere. In a survey done in $\mathrm{Ga}$ Rankuwa $(\mathrm{n}=218)$, the prevalence of hypertension and obesity were higher than the national prevalence for South Africa. The waist-hip ratio indicated that $20 \%$ of the men and $49.7 \%$ of the women were at risk of contracting cardiovascular disease. Above normal blood glucose levels were present in $21.6 \%$ of the group and the level of physical activity was inadequate (Wright \& Ramukumba, 2008:73). A decision was taken to undertake a larger study to determine the prevalence of risk factors relating to cardiovascular disease and measure the knowledge and awareness of the popula- 
tion regarding these risk factors.

\section{PURPOSE OF THE STUDY}

The purpose of the study was to generate communityspecific guidelines to promote cardiovascular wellness in the Ga-Rankuwa community. The focus of this article is on a subset of the main study, namely the knowledge and awareness of risk factors among the working-age people in the Ga-Rankuwa community. Registered professional nurses and health promoters need this baseline information to be able to plan and implement evidence-based interventions.

\section{THEORETICAL BASIS OF THE STUDY}

The theoretical basis of the study is the health promotion model (Pender, Murdaugh \& Parsons, 2002:7). This model is proposed as a framework for integrating nursing and behavioural science perspectives into factors influencing health behaviours (Pender et al., 2002:60). As the health promotion model has several categories of determinants, the study was based on the following specific ones:

- Individual characteristics and experiences, for example biological, psychological and sociocultural.

- Prior related behaviour, which is proposed as having both direct and indirect effects on the likelihood of engaging in health-promoting behaviour.

- Behaviour-specific cognitions and affect categories, including perceived benefits of action, perceived barriers to action and perceived selfefficacy.

- Interpersonal influences, which are cognitions concerning the behaviours, beliefs or attitudes of others; primary sources include family, peers and providers, and others include norms, social support and modelling.

- Situational influences such as perceptions of options, demand characteristics and aesthetics in which a given behaviour is likely to take place.

- Lastly, commitment to a plan of action and immediate competing demands.

Pender et al. (2002:12) consider behaviour-specific cognitions and affect categories to be of major motiva- tional significance and subject to modification through nursing care.

\section{RESEARCH METHODS AND DESIGN}

The research methodology will be described in terms of the context, research design, data gathering and data analysis.

\section{Context}

The geographical location for the study was GaRankuwa, a town $35 \mathrm{~km}$ north of Pretoria in Tshwane. According to Stats Council Census (South Africa, 2001), the estimated population of the town was 83900 people in 2001, but this number is growing at a rapid rate. The majority of the population are black $(99.6 \%)$, with $74 \%$ speaking Setswana.

\section{Research design}

The research design was a quantitative survey (Burns \& Grove, 2001:28). A study was conducted to generate community-specific guidelines to promote cardiovascular wellness in the Ga-Rankuwa community. Two concurrent surveys were conducted. The first survey sought to determine the prevalence of cardiovascular disease risk factors in the Ga-Rankuwa community. The focus of this article is the second survey, which investigated the knowledge and awareness of cardiovascular disease among working-age people living in Ga-Rankuwa.

\section{Population}

The target population for the study was working-age people (18-40 years) living in the Ga-Rankuwa community. The rationale for using working-age people was the need to identify and reduce risk factors in this age group in order to reduce the likelihood of cardiovascular disease in later life. The total population living in the Ga-Rankuwa community could not be included in the sample owing to economic and practical constraints. Four zones, zones 1, 2, 4 and 16, of Ga-Rankuwa were chosen for the study because of their close proximity to one another. A census sample was used, as a doorto-door survey was undertaken. The survey was undertaken from July to October 2005. The sample size was $604(n=604)$. The knowledge and awareness survey 
sample was a subset of the prevalence of risk factors for cardiovascular disease survey and only people with an identified risk factor were included in the knowledge and awareness survey $(n=551)$.

\section{Data gathering}

The data-gathering method was self-report (Burns \& Grove, 2001:422) using a structured interview. The unknown literacy level of the respondents guided this decision. The data-gathering instrument was a structured questionnaire (Burns \& Grove, 2001:421). The knowledge and awareness questionnaire and the cardiovascular risk factors survey ran concurrently. Once the respondents had completed the cardiovascular risk factors survey and the physical measurements had been taken, the researcher identified the respondents who had one or more risk factors for cardiovascular disease. Only these respondents were then invited to participate in the knowledge and awareness survey (Li \& Wright, 2007).

There were several advantages to completing the second questionnaire immediately:

- There was no attrition of participants.

- The participants of the first survey were questioned.

- The participants had no time to gain knowledge about cardiovascular risk factors.

- Doing both questionnaires during the same visit improved the feasibility of the research.

- The study was conducted according to accepted international ethical principles. The Ethics Committee of Tshwane University of Technology approved the proposal.

\section{Data analysis}

The data were analysed using descriptive statistics and the SPSS 13.0 program. The analysis was presented in frequency tables and figures.

\section{Validity and reliability}

Several measures were put in place to ensure the validity and reliability of the study. The questionnaire was based on the Canadian Heart Health Surveys database proposed by Kirkland et al. (1999:col.161) and was validated by a pre-test. The pre-test was undertaken in a similar area in Tshwane (Li \& Wright, 2007). No problems in terms of misunderstanding or the data generated were identified during the pre-test. Consistency was maintained in the research team as the same team gathered the data. As the data were gathered during the same visit, there was therefore no attrition of participants and no additional knowledge could be gained by the participants.

\section{RESULTS OF KNOWLEDGE AND AWARE- NESS OF CARDIOVASCULAR RISK FAC- TORS}

The results will be presented in terms of the demographic profile, knowledge and awareness.

\section{Demographic profile}

More males (302 versus 249 females) participated in the study, with the highest number of respondents (33.8\% males and $37.4 \%$ females) in the $18-24$ year age group. A high percentage, above $85 \%$ for both males and females, had secondary or tertiary education.

\section{Awareness of risk factors for cardiovas- cular disease}

The respondents were asked, "Can you tell me, in your opinion, what the major causes of heart disease are?" The results are illustrated in Figure 1. Both males and females mentioned stress most frequently $(53.5 \%$ and $50.3 \%$, respectively). The second most frequent response was smoking. Though more females were aware of an unhealthy diet as a risk factor in cardiovascular disease $(36.3 \%$ females and $30.1 \%$ males, respectively), obesity was mentioned by only $21.7 \%$ of the females and $13.3 \%$ of the males. Females were more knowledgeable about and aware of hypertension, but the levels were still low $(24.9 \%$ females and $18.5 \%$ males, respectively). The general level of knowledge and awareness of alcohol consumption, diabetes mellitus and a positive family history was low $(<15 \%)$.

The influence of a positive risk factor status on the respondents' knowledge and awareness was investigated. A respondent was considered to have a positive risk factor status if he/she was diagnosed with the specific risk for cardiovascular disease. Four frequent risk factors, namely smoking, physical inactivity, hypertension 


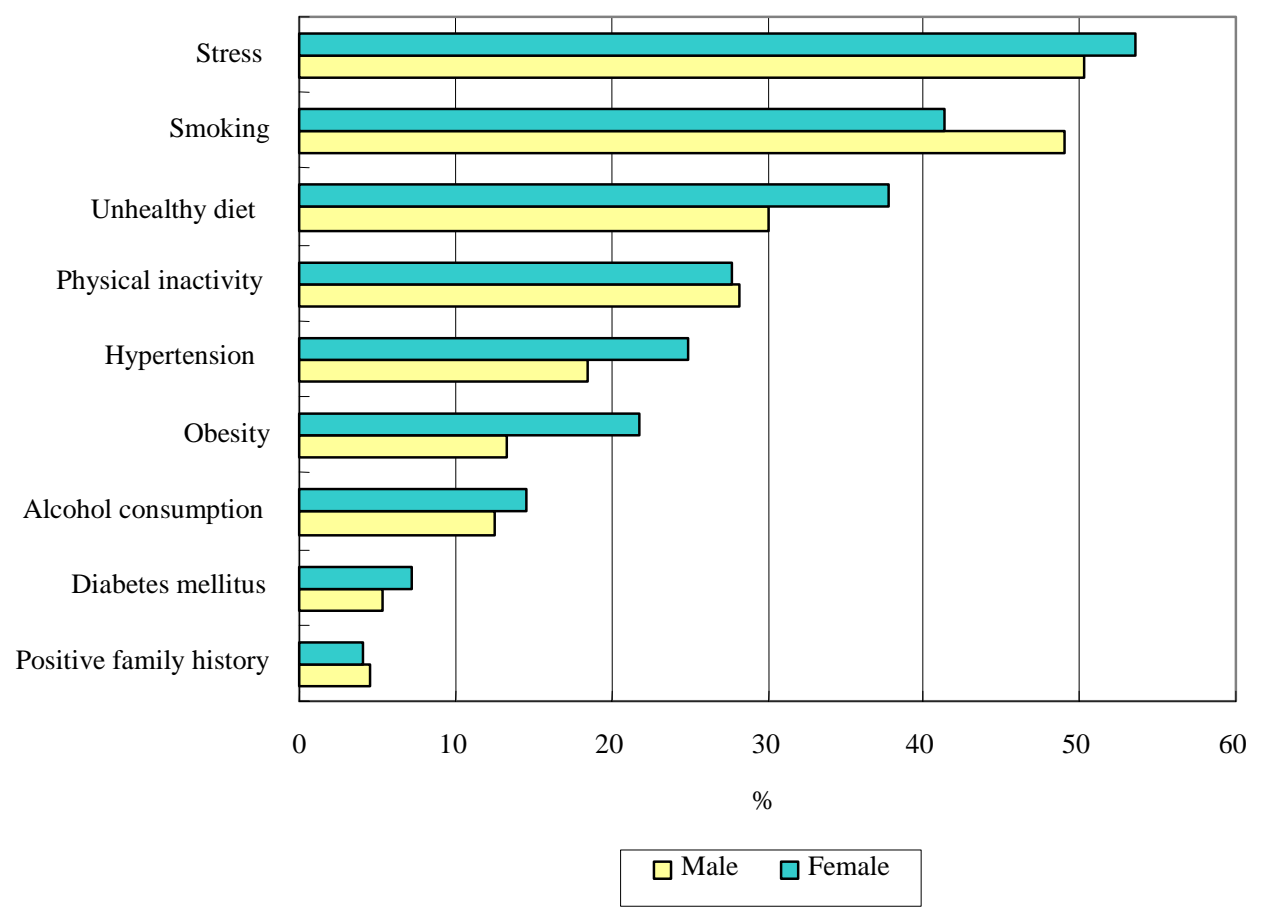

Figure 1: Levels of knowledge and awareness of the risk factors for cardiovascular disease $(n=551)$

and obesity, were investigated (Table 1). In both male and female smokers, approximately $60 \%$ were knowledgeable about and aware of the inherent risks of smoking for cardiovascular disease. There was a significant difference $(p<0.01)$ between smoking males and nonsmoking males concerning smoking as one of risk factors for cardiovascular disease.

In terms of physical inactivity, hypertension and obesity, the level of awareness was below $30 \%$. Of particular concern are the low levels of awareness regarding hypertension, which is considered to be the most significant of these risk factors (Vokonas, Kannel \& Cupples, 1988:S3). In the hypertensive group, only $24.0 \%$ of the males and $22.2 \%$ of the females were aware of the risk.

Another problem area is awareness regarding obesity. The overall level of awareness was $19.6 \%$ in the positive risk factor group. The male group had the lowest awareness regarding the risks associated with obesity. Even in the male group with tertiary education, only $18.2 \%$ were aware of the inherent risks compared to $26.9 \%$ of females with the same educational level.

For the risk factors investigated, no clear trend could be determined with regard to educational level. There was, however, a positive trend between higher age and awareness

\section{Knowledge of hypertension and diabetes mellitus}

Owing to the importance of hypertension and diabetes mellitus, the participants' knowledge of hypertension and the complications that could arise was investigated. 49 respondents were knowingly hypertensive $(n=49)$. From within the hypertensive group, a third of the respondents considered their blood pressure to be normal. A further third did not accurately know their blood pressure level. In the hypertensive group, $30.8 \%$ of the males and $37 \%$ of the females did not specifically know what their blood pressure was.

Knowledge of the complications of hypertension was low. In all categories, the female group was more knowledgeable than the male group. Stroke was mentioned most frequently as a complication of uncontrolled hypertension (39.8\% females versus $21.2 \%$ males). Myocardial infarction (overall $18.7 \%$ ) was also mentioned. In all the gender and age categories, the majority of the respondents were unaware that a stroke, heart attack, heart angina, heart failure and kidney failure were complications of hypertension.

Self-reported diabetes mellitus was limited; only nine 
respondents $(1.5 \%)$ of the total sample suffered from diabetes mellitus (Li \& Wright, 2007). Stroke was mentioned most frequently as a complication (23.9\% females versus $10.9 \%$ males). As with hypertension, in all the gender and age categories, the majority of the group were not aware that the short-term complications of diabetes mellitus are hypoglycaemia or hyperglycaemia and keto-acidosis. Long-term complications are cardiac disease, hypertension and damage to kidneys, eyes and peripheral neuropathy.

\section{Knowledge and awareness of lifestyle modification to prevent cardiovascular disease}

Respondents were asked: "In your opinion, how can cardiovascular disease be prevented?" Figure 2 presents the lifestyle modifications listed by the respondents. The lifestyle modifications most frequently mentioned were doing exercise $(41.4 \%)$, reducing stress (40.8\%) and stopping smoking (40.7\%). Again, modifications that might have been listed first by a biomedically trained person, for example controlling hypertension and weight, as well as a healthy diet, were almost last on the list. Only $12.0 \%$ thought that controlling hypertension was advisable, and $14.3 \%$ mentioned reducing weight.
There was no obvious trend in terms of age for a specific lifestyle modification. In terms of gender, females were more knowledgeable about and aware of factors such as controlling weight and hypertension, as well as reducing stress. Interestingly, when asked to list risk factors for cardiovascular disease, half the respondents $(53.5 \%)$ mentioned stress as a risk factor for cardiovascular disease (Figure 1). However, compared with reducing stress, more respondents thought that it was important to do exercise to prevent cardiovascular disease.

\section{Knowledge and awareness of healthy di- etary practices}

The results depicted in Table 2 reflect the respondents' awareness of body weight. About a third of the males (30.1\%) were overweight, obese or severely obese compared to $61.8 \%$ of the females. In the male group, only $14.6 \%$ considered themselves to be obese, and $78.5 \%$ acknowledged a connection between obesity and cardiovascular disease. The female group presented another picture. Six out of every ten $(61.8 \%)$ were overweight, obese or severely obese, but only three out of ten $(29.7 \%)$ perceived themselves to be so.

To further investigate the relationship between meas-

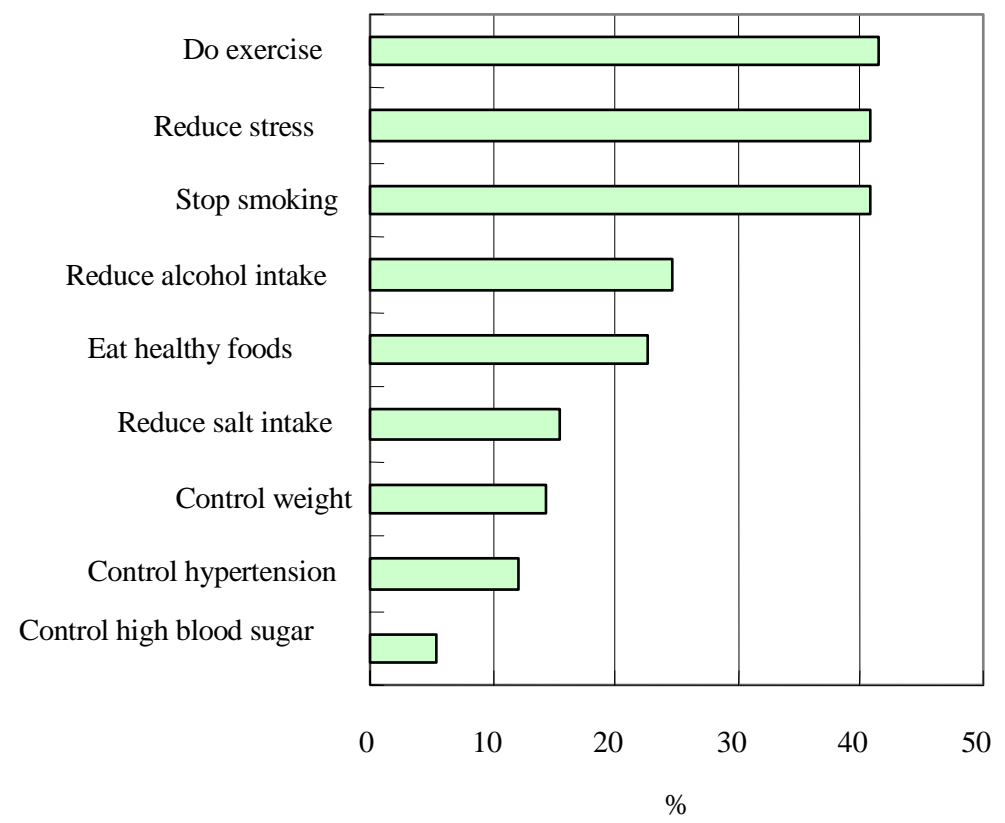

Figure 2: List of lifestyle modifications $(n=551)$ 
Table 2: Knowledge and awareness of body weight $(n=551)$

\begin{tabular}{llcll}
\hline $\begin{array}{l}\text { Body mass index and knowledge } \\
\text { of body weight }\end{array}$ & $\begin{array}{l}\text { Male } \\
\mathbf{n}\end{array}$ & $\begin{array}{l}\text { Female } \\
\mathbf{n}\end{array}$ & $\%$ \\
\hline Body mass index $<25 \mathrm{~kg} / \mathrm{m} 2$ & 211 & 69.9 & 95 & 38.2 \\
Body mass index $\geq 25 \mathrm{~kg} / \mathrm{m} 2$ & 91 & 30.1 & 154 & 61.8 \\
Do you consider yourself to be: & & & & \\
Obese & 44 & 14.6 & 74 & 29.7 \\
Normal weight & 39 & 12.9 & 18 & 7.2 \\
Underweight & 219 & 72.5 & 157 & 63.1 \\
\hline
\end{tabular}

Table 3: BMI cross-tabulated with knowledge and awareness of body weight $(n=551)$

\begin{tabular}{|c|c|c|c|c|c|c|}
\hline \multirow[t]{2}{*}{ Sex and body weight } & \multicolumn{2}{|c|}{ Obesity } & \multicolumn{2}{|c|}{ Normal weight } & \multicolumn{2}{|c|}{ Underweight } \\
\hline & $\mathrm{n}$ & $\%$ & $\mathrm{n}$ & $\%$ & $\mathrm{n}$ & $\%$ \\
\hline \multicolumn{7}{|l|}{ Male } \\
\hline $\begin{array}{l}\mathrm{BMI} \geq 25 \mathrm{~kg} / \mathrm{m} 2 \text { consider body } \\
\text { weight to be }\end{array}$ & 34 & 37.4 & 3 & 3.3 & 54 & 59.3 \\
\hline $\begin{array}{l}\mathrm{BMI}<25 \mathrm{~kg} / \mathrm{m} 2 \text { consider body } \\
\text { weight to be }\end{array}$ & 10 & 4.7 & 36 & 17.1 & 165 & 78.2 \\
\hline Female & & & & & & \\
\hline $\begin{array}{l}\mathrm{BMI} \geq 25 \mathrm{~kg} / \mathrm{m} 2 \text { consider body } \\
\text { weight to be }\end{array}$ & 66 & 42.8 & 9 & 5.8 & 79 & 51.4 \\
\hline $\begin{array}{l}\mathrm{BMI}<25 \mathrm{~kg} / \mathrm{m} 2 \text { consider body } \\
\text { weight to be }\end{array}$ & 8 & 8.4 & 9 & 9.5 & 78 & 82.1 \\
\hline
\end{tabular}

ured weight and perception regarding weight, body mass index (BMI) categories were cross-tabulated with the respondents' perception of their weight. From Table 3 it is clear that the respondents' knowledge and awareness of weight were different from those of a biomedically trained health care worker. For both males and females with a BMI of $=25 \mathrm{~kg} / \mathrm{m} 2$, only $37.4 \%$ of the males and $42.8 \%$ of the females actually considered themselves to be obese. Even more alarming was the fact that $59.3 \%$ of the males and $51.4 \%$ of the females considered themselves to be underweight.

Knowledge and awareness of salt intake were also investigated. The results indicate that $72.2 \%$ of the males and $72.3 \%$ of the females reported that they enjoyed their food lightly salted. Only $30.1 \%$ of the males and $36.6 \%$ of the females knew what amount of salt was recommended for a person with cardiovascular disease.

The respondents' knowledge and awareness of the number of fruit and vegetable portions that should be eaten per day were investigated. Only a minority of respondents were knowledgeable and aware that people should eat at least five fruit and vegetable portions per day $(7.3 \%$ of the males and $4.4 \%$ of the females, respectively). The respondents' level of education was cross-tabulated with their knowledge and awareness of a healthy diet. Lower education was associated with lower knowledge of a healthy diet. In the study sample, nearly two out of five respondents with primary school 
or lower education indicated that a person need not eat any fruit or vegetable portions per day (16.7\% fruit and $19.5 \%$ vegetables). However, there were also some respondents with tertiary education (14.5\%) who did not know that they needed to eat fruit and vegetables every day.

\section{DISCUSSION OF THE RESULTS}

The study provided a unique opportunity to examine knowledge and awareness of cardiovascular risk factors among the working-age people of the Ga-Rankuwa community.

Results from the study indicate that the knowledge and awareness of risk factors for cardiovascular disease in people of 18-40 years old were generally low. The finding that knowledge and awareness of smoking as a risk factor of cardiovascular disease was comparatively high (40\%) may reflect some success of public health interventions and health promotion messages regarding smoking that have been targeted at the wider population in the last few decades. In contrast, despite the fact that the respondents reported stress as a risk factor most frequently, public health efforts have largely ignored the condition as a risk factor for cardiovascular disease.

As reported in Figure 1, respondents did not recognise the common ground in several of the risk factors. For example, approximately $33 \%$ listed an unhealthy diet as a risk factor, but only $12 \%$ considered obesity as a risk factor. The link between diet and obesity was not well understood by those in the study sample. Another example was obesity, physical inactivity and diabetes mellitus. Almost 30\% listed physical inactivity as a risk factor, as compared to only $5 \%$ who listed diabetes mellitus as a risk factor. The influence that the body's systems have on one another was poorly understood in the study sample.

Knowledge and awareness of the risk factors were investigated according to the risk status of the respondents, to determine whether being positive for certain of these factors influenced knowledge and awareness. The only risk factor that altered the knowledge and awareness among male respondents was smoking (Table 1). The presence of hypertension, physical inactivity and obesity in the female group did not alter the level of knowledge and awareness. A person's perception of a threat posed by a health problem is associated with actions aimed at reducing the threat (Pender et al., 2002:36). A conclusion is that females do not perceive a threat, therefore no value is attached to a measurement such as a BMI of $=25 \mathrm{~kg} / \mathrm{m} 2$. A health promotion intervention that does not consider these facts will not be successful.

According to the health promotion model, personal factors such as sociocultural factors are cited as having both direct and indirect effects on the likelihood of engaging in health-promoting behaviour (Pender et al., 2002:7). If a specific culture associates a physical characteristic such as obesity with respect, confidence and affluence, and being thin carries with it the stigma of potentially being HIV positive, it is difficult to change knowledge and awareness. This point is supported by the results. While $61.8 \%$ of the female group was classified as overweight, obese or severely obese, more than half still considered themselves to be underweight. Furthermore, the study concludes that a higher level of education is associated with a higher prevalence of some risk factors (Li \& Wright, 2007). In some respects, being poor may in fact safeguard people against longterm cardiovascular risks.

Knowledge and awareness of risk factors are essential components of behaviour change (Kirkland et al., 1999:col.161). If obesity is used as an example, the chances of a successful health promotion outcome are minimal. The fact that obesity is not recognised, the long-term threat is not perceived or understood, and the outcome is not desirable (Pender et al., 2002:50) makes the likelihood of action to reduce weight improbable. The same is true for risk factors such as hypertension, unhealthy diet and physical inactivity.

The results of knowledge and awareness of hypertension correspond with the Mamre Hypertension Project (Metcalf, Hoffman, Steyn, Katzenellenbogen \& Fourie, 1996:22), which confirmed the need for an intervention programme that included improved blood pressure screening services and improved management of known hypertension. Smith, Lee, Crombie and Tunstall-Pedoe (as quoted by Metcalf et al., 1996:22) state that the 'rule of halves' has been proposed as a typical description of treatment for hypertension in a population. The 'rule of halves' claims that half of all hypertensive pa- 
Table 1: Knowledge and awareness according to risk factor status

\begin{tabular}{lccccc}
\hline Risk factor & \multicolumn{2}{c}{ Risk factor positive (aware) } & \multicolumn{2}{c}{ Risk factor negative (aware) } & X2 \\
& $\mathbf{n}$ & $\%$ & $\mathbf{n}$ & $\%$ & \\
\hline Smoking & & 58.7 & 77 & 42.5 & $7.56^{*}$ \\
Male & 71 & 59.1 & 90 & 39.7 & 2.38 \\
Female & 13 & 58.7 & 167 & 40.8 & $13.54^{* *}$ \\
Total & 84 & & & & \\
Physical inactivity & 17 & 27.0 & 68 & 28.5 & 0.05 \\
Male & 17 & 21.3 & 56 & 29.8 & 1.65 \\
Female & 13 & 24.2 & 124 & 29.0 & 1.12 \\
Total & 30 & & & & \\
Hypertension & 12 & 24.0 & 44 & 17.5 & 0.12 \\
Male & 10 & 22.2 & 52 & 25.5 & 0.21 \\
Female & 10 & 96 & 21.0 & 0.27 \\
Total & 22 & 23.2 & & & \\
Obesity & & & 23 & 10.9 & 3.35 \\
Male & 17 & 18.7 & 23 & 24.2 & 0.58 \\
Female & 31 & 20.1 & 46 & 15.0 & 1.99 \\
Total & 48 & 19.6 & &
\end{tabular}

${ }^{* *} p<0.001{ }^{*} p<0.01$

tients are known to health services; half of those who are known are treated, and half of those are treated inadequately. However, hypertensive respondents in the study sample had a lower level of knowledge and awareness of their hypertensive status, a lower percentage were on treatment, and had a higher level of hypertension control overall than those in the Mamre Hypertension Project. Health personnel may need to consider how to assist unhealthy people with chronic conditions. People who reside in informal settlements may not have access to sanitation; they may reduce or omit to take their medication in order to avoid the inconvenience of going out to a toilet during the night. The socio-economic status of an individual can also constitute a barrier to compliance with treatment.

Knowledge and awareness of diet and cardiovascular disease were found to be very poor, particularly with regard to quantification of salt intake, as well as the recommended number of fruit and vegetable portions to be consumed daily. An intake of at least five portions $(400 \mathrm{~g})$ of fruit and vegetables per day is recommended as a healthy guideline for adults to ensure a sufficient intake of potassium (Love \& Sayed, 2001:24). The study identified that the level of school education has an association with the knowledge of healthy dietary behaviour. Lower education was associated with lower knowledge of a healthy diet. Most other studies seem to indicate that higher socio-economic status is associated with healthy dietary behaviour (Smith \& Owen, 1992:735). For instance, in Australia a higher dietary fat intake and a lower dietary fibre intake have been found among lower socio-economic groups compared to higher status groups (Smith \& Baghurst, 1992:409). Steptoe and Wardle (1999:391) found among a representative sample in Britain that fibre consumption was inversely associated with socio-economic status, and that those with higher education ate more fibre, fruit, vegetables and cereals than those with lower education.

Working from the perspective of the health promotion model (Pender et al., 2002:68), some possible reasons for the low knowledge and awareness of risk factors for cardiovascular disease can be put forward. According to the model, situational influences such as a lack of 
mass media and posters on risk factors for cardiovascular disease available in communal places can influence the knowledge and awareness of those risk factors. With the focus currently falling on HIVIAIDS, malaria and tuberculosis, other chronic non-communicable diseases are neglected in health promotion literature (Lenfant, 2001:984).

Important aspects that should be taken into account in follow-up interventions are as follows:

- The overall level of knowledge and awareness of risk factors related to cardiovascular disease is low.

- More respondents consider stress as a risk factor related to cardiovascular disease than any other risk factor, including smoking.

- A positive risk status does not necessarily correlate with higher knowledge and awareness.

- The reality of obesity and the respondents' perception of it present a challenge which is not fully appreciated.

- Dietary knowledge and awareness are lacking and not sufficient to serve as a basis for an intervention. Educating the community about dietary practices should be part of a health promotion intervention.

- $\quad$ The role of the local primary health care clinic in educating the community on other diseases is non-existent, because only HIVIAIDS, malaria and tuberculosis are featured.

\section{LIMITATIONS OF THE STUDY}

The limitations of the study are the following:

- Only zones 1, 2, 4 and 16 of Ga-Rankuwa were chosen for the purpose of the study. Consequently, although a census sample was used, the results cannot be generalised to the whole community.

- The study focused on working-age people, therefore no inference can be made concerning the prevalence of the risk factors in elderly people.

- The data gathered are self-reported, and therefore subject to both recall and social desirability bias.

\section{RECOMMENDATIONS}

Although the research study provided some answers to the question on the knowledge and awareness of cardiovascular disease, it uncovered various areas in which further research is essential. Recommendations for further research are as follows:

- The health literacy of the community must be determined so that this can be used as a basis for all future health promotion interventions.

- The social determinants of health in the community must be investigated to serve as a building block for future interventions.

- The risk factors for cardiovascular disease must be investigated in all age groups in $\mathrm{Ga}$ Rankuwa.

- Owing to the importance attached to stress as a risk factor by the respondents, stress levels should be investigated. Is the frequent listing a result of exposure to media or a perceived need in the community? The current study has no answer to this question.

- Dietary practices should be researched in depth to be able to design community-specific interventions.

- Changes in lifestyle are important in the prevention of cardiovascular disease. There is limited information on physical activity in the community, and no evidence of attempts to address the levels of physical inactivity.

\section{CONCLUSION}

There were low levels of knowledge and awareness of the risk factors for cardiovascular disease in the GaRankuwa community. The results of a lack of knowledge and awareness of risk factors should enjoy more attention and specific interventions must be developed to educate the community of Ga-Rankuwa. It is important to initiate a health project to improve the knowledge and awareness of risk factors for cardiovascular disease in the Ga-Rankuwa community.

\section{REFERENCES}

ANDERSON, GF \& CHU, E 2007: Expanding priorities: Confronting chronic disease in countries with low income. The New England Journal of Medicine, 356(3):209-211. 
BRADSHAW, D; NANNAN, N; LAUBSER, R; GROENEWALD, P; JOUBERT, J; NOJILANA, B; NORMAN, R; PIETERSE, D \& SCHNEIDER, M 2003: South African burden of disease study: Provincial estimates of mortality. Medical Research Council: Burden of Disease Unit.

BURNS, N \& GROVE, SK 2001: The practice of nursing research: Conduct, critique, \& utilization. Philadelphia: WB Saunders.

HOSSAIN, P; KAWAR, B \& EL NAHAS, M 2007: Obesity and diabetes in the developing world-A growing challenge. New England Journal of Medicine, 356:213-215.

KIRKLAND, SA; MACLEAN, DR; LANGILLE, DB; JOFFRES, MR; MACPHERSON, KM \& ANDREOU, P 1999: Knowledge and awareness of risk factors for cardiovascular disease among Canadians 55 to 74 years of age: Results from the Canadian heart health surveys. Canadian Medical Association Journal, 161(8):S10. LENFANT, C 2001: Can we prevent cardiovascular diseases in low- and middle-income countries? Bulletin of the World Health Organization, 79(10):980-982 .

LI, YQ \& WRIGHT, SCD 2007: Guidelines to promote cardiovascular wellness in Ga-Rankuwa community. Pretoria: Tshwane University of Technology (Unpublished MTech: Nursing dissertation). LOVE, P \& SAYED, N 2001: Eat plenty of vegetables and fruits everyday. South African Journal of Clinical Nutrition, 14(3):s24-s31.

MCTIGUE, K; LARSON, JC; VALOSKI, A; BURKE, J; KOTCHEN, J; LEWIS, C; STEFANICK, M; VAN HORN, L \& KULLER, L 2006: Mortality and cardiac and vascular outcomes in extremely obese women. Journal of the American Medical Association, 296(1):79-86.

METCALF, CA; HOFFMAN, MN; STEYN, K; KATZENELLENBOGEN, JM \& FOURIE, JM 1996: Design and baseline characteristics of a hypertension intervention programme in a South African village. Journal of Human Hypertension, 10(1), Jan:21-26.

PENDER, NJ; MURDAUGH, CL \& PARSONS, MA 2002: Health promotion in nursing practice; $4^{\text {th }}$ edition. Julie Alexander: Prentice Hall.

SMELTZER, SC \& BARE, BG 1996: Bruner and Suddart's textbook of medical-surgical nursing; $8^{\text {th }}$ edition. Philadelphia: Lippincott. SMITH, AM \& BAGHURST, KI 1992: Public health implications of dietary differences between social status and occupational category groups. Journal of Epidemiology and Community Health, 46:409-416.

SMITH, AM \& OWEN, N 1992: Associations of social status and health-related beliefs with dietary fat and fiber densities. Preventive Medicine, 21(6), Nov:735-745.

SOUTH AFRICA. Stats Council Census. 2001: Census 2001 figures for Ga-Rankuwa. http://www. statssa.gov.za/extract.htm (Accessed on 18 March 2006).

STEPTOE, A \& WARDLE, J 1999: Motivational factors as mediators of socioeconomic variations in dietary intake patterns. Psychology and Health, 14(3):391-402.

VOKONAS, PS; KANNEL, WB \& CUPPLES, LA 1988: Epidemiology and risk of hypertension in the elderly: The Framingham study. Journal of Hypertension, 6(1):S3-9.

WALKER, ARP; BALLARD, R; RAAL, FJ; VERMAAK, WJH; DELPORT, R; SHOR, A \& BRINK, AJ 2000: Changing concepts of coronary artery disease - Part 1 , round-table discussion. Cardiovascular Journal of South Africa, 11(1), Feb:32-40.

WHO - see World Health Organization.

WORLD HEALTH ORGANIZATION 2003: Diet, nutrition and the prevention of chronic diseases. http://www.who.int/hpr/NPH/docs/ who_fao_expert_report.pdf (Accessed on 12 January 2007). WRIGHT, SCD \& RAMUKUMBA, TS 2008: Life style risk factors in an urban South African community: How to proceed? Curationis, 31(1):68-76. 